\title{
PENGENALAN DAN PELATIHAN PEMROGRAMAN DASAR BLOCKLY KEPADA SISWA SMA AL AZHAR 1, 2 DAN 3
}

\author{
Riri Safitri $^{1^{*}}$, Ade Jamal ${ }^{1}$, Endang Ripmiatin ${ }^{1}$, Denny Hermawan ${ }^{1}$, Arif Supriyanto ${ }^{1}$ \\ ${ }^{I}$ Teknik Informatika, Fakultas Sains dan Teknologi, Universitas Al Azhar Indonesia, \\ Jalan Sisingamangaraja, Kompleks Masjid Agung Al Azhar, Kebayoran Baru, Jakarta Selatan 12110 \\ Email Penulis Korespodensi: riri@uai.ac.id
}

\begin{abstract}
Abstrak
Teknologi komputer mempengaruhi setiap bidang kehidupan saat ini. ia masuk dan mengubah setiap bidang di dunia, mulai dari industri dan bisnis, transportasi, komunikasi, kesehatan, dan lain-lain. Setiap siswa memiliki kesempatan yang sama untuk mempleajari dan menguasai teknologi, belajar coding, menguasai algoritma, mempelajari bagaimana cara membuat aplikasi, bagaimana internet bekerja, dalam rangka memupuk kreativitas dan keterampilan menyelesaikan masalah (problem solving) yang akan sangat berguna bagi kehidupan mereka di masa depan. Program komputer/perangkat lunak atau software akan menjadi hal yang sangat penting, bahkan mungkin akan menjadi bahasa dunia ke depan. Tidak menguasai programming atau bahasa komputer di masa depan, akan sama efeknya dengan tidak bias baca tulis saat ini. Belajar ilmu komputer tidak hanya belajar tentang teknologi itu sendiri, namun juga belajar logika, penyelesaian masalah (problem solving), dan kreativitas. Oleh karena itu perlu adanya pengenalan dan pelatihan pemrograman untuk siswa sekolah untuk melatih kemampuan logika dan problem solving. Pelatihan pemrograman diberikan dalam bentuk simulasi Blockly berupa games yang menarik dan interaktif. Hasil dari pelatihan didapatkan bahwa siswa SMA peserta pelatihan merasa kegiatan ini sangat menarik dan bermanfaat dan dapat menambah pamahaman dan keterampilan mereka dalam hal IT dan penerapannya.
\end{abstract}

\section{Kata kunci: Coding, Komputer, Pemrograman, TIK}

\begin{abstract}
Computer technology affects every area of life today. he entered and changed every field in the world, starting from industry and business, transportation, communication, health, and others. Every student has the same opportunity to learn and master technology, learn coding, master algorithms, learn how to make applications, how the internet works, in order to foster creativity and problem solving skills that will be very useful for their lives in the future. Computer / software or software programs will be very important, maybe even become the world language in the future. Not mastering programming or computer language in the future, it will have the same effect as the current non-literacy. Learning computer science not only learns about technology itself, but also learns logic, problem solving, and creativity. Therefore there is a need for introduction and programming training for school students to practice logic and problem solving skills. Programming training is provided in the form of Blockly simulations in the form of interesting and interactive games. The results of the training found that high school students participating in the training felt this activity was very interesting and useful and could add to their understanding and skills in terms of IT and its application.
\end{abstract}

Keywords: Coding, Computer, Computer Science, Programming 


\section{PENDAhUluan}

Perubahan-perubahan yang sangat cepat dan mengakibatkan pergeseran geliat ekonomi semakin ramai dibahas yang kemudian dikenal dengan istilah disruptive economy dan disruptive innovation. Disruptive economy, sebenarnya bukanlah hal yang baru. Revolusi industri adalah disruptive economy yang menggeser ekonomi dari berbasiskan pertanian ke industri manufaktur; lalu revolusi digital menggeser perkonomian industri manufaktur ke pelayanan digital. Inovasi dalam informasi dan disruptive technologies lainnya cenderung meningkatkan produktivitas dengan mengganti pekerja yang ada, daripada menciptakan produk baru yang membutuhkan lebih banyak tenaga kerja untuk menghasilkannya (World Economic Forum, 2018)

Disruptive yang saat ini dibahas adalah pergeseran karena revolusi internet, yang sering diartisempitkan pada revolusi Big Data. Untuk mengejar ketinggalan akibat revolusi industri maupun digital, suatu bangsa bisa dengan cara cepat melakukan loncatan dengan mengirim mahasiswa belajar ke luar negeri atau membiarkan bangsa lain yang lebih maju mendirikan Perguruan Tinggi yang sudah siap untuk era industri dan digital. Hal ini pernah dilakukan Malaysia dan Indonesia, dimana negara kita relatif kurang berhasil dibandingkan negara tetangga kita.

Perhatian khusus pada pendidikan tinggi bisa dilakukan untuk menghadapai ketinggalan revolusi industri dan digital, karena sistem pendidikan dasar dan menegah pada saatnya akan mengejar ketinggalan sudah disiapkan dengan ilmu-ilmu dasar yang dibutuhkan yaitu matematika, bahasa dan sains. Untuk menghadapi revolusi internet, negara sebesar Ameriksa Serikat masih melakukan gerakan perubahan pada sistem pendidikan dasar dan menengah. Hal ini dilakukan untuk menyiapkan sumber daya manusia yang dibutuhkan dalam mendukung era internet dan menyongsong eraera baru lainnya yang akan segera menyusul era internet ini. Pertumbuhan penggunaan internet terus meningkat di seluruh dunia, dengan jumlah pengguna global meningkat lebih dari $80 \%$ dari tahun 2012 (We Are Social, LTD, 2017).

Revolusi Internet pada akhir abad 20, mengharuskan setiap siswa juga mempunyai kesempatan belajar tentang algortima, bagaiamana membuat program komputer, bagamana internet bekerja, seperti halnya mereka mempunyai kesempatan belajar tentang termodinamika dan biologi, bagaimana panas bisa mengalir dari satu media ke media lain dan bagaimana tumbuhan dapat berkembang biak.

Kondisi mitra saat ini, yaitu SMA Al Azhar 1, 2 dan 3 khususnya dan umumnya di SMA SeIndonesia sudah tidak ada mata pelajaran TIK. Mata pelajaran ini ditiadakan karena dianggap siswa lebih cepat beradaptasi dengan perkembangan teknologi informasi. Namun permasalahannya bukan hanya di mata pelajaran TIK dimasukkan dalam kurikulum atau tidak. Hal yang lebih mendasar lagi adalah perlu adanya perbaikan dari materi yang diberikan dalam mata pelajaran TIK. Dengan adanya mata pelajaran TIK diharapkan siswa-siswa tidak hanya beradaptasi dan menjadi konsumen dari produk-produk digital yang tersebar saat ini, namun siswa harus mempunyai kemampuan logika, problem solving sehingga mampu menjadi produsen dari produk-produk digital yang bermanfaat bagi banyak orang.

Alasan utama bahwa ilmu komputer sekarang harus menjadi ilmu dasar yang sangat diperlukan pada setiap sekolah karena dengan ilmu ini siswa diberikan kemampuan untuk memikirkan sebuah masalah dengan cara yang berbeda. Ilmu komputer adalah disiplin ilmu dengan pengetahuannya sendiri yang dapat membekali siswa untuk menjadi pembelajar yang mandiri, evaluator dan perancang teknologi baru (Csizmadia, 2017). Siswa akan mendapatkan kemampuan berfikir komputasional yang sistematis, yang termasuk didalamnya cara berfikir yang lebih kuat (robust) dalam melihat sebuah masalah.

Teknik penyelesaian masalah ini akan dapat diterapkan pada segala bidang ilmu dan setiap masalah yang ada. Jika menghadapai masalah yang ukurannya besar dan pekerjaannya yang belum pasti, misalnya pada pekerjaan rumah, cara berfikir komputasional dan teknik penyelesaian masalah dari ilmu komputer akan mengarahkan untuk memecah masalah besar ini menjadi masalah-masalah yang lebih kecil agar lebih mudah diselesaikan secara sistematis. Mengenali apa-apa yang lebih penting yang harus diselesaikan pertama kali, adalah keterampilan berfikir kritis yang sangat penting pada setiap keadaan. 


\section{METODE PELAKSANAAN}

Untuk menjawab permasalahan yang telah dijelaskan sebelumnya, maka solusi yang ditawarkan adalah dengan memberikan sosialisasi akan pentingnya ilmu komputer sebagai ilmu dasar yang harus dimiliki oleh siswa-siswa di sekolah. Kegiatan sosialisasi dilanjutkan dengan memberikan pelatihan pengenalan ilmu komputer, khususnya pemrograman (coding) sederhana dengan bantuan aplikasi yang menarik untuk siswasiswa sekolah.

Pelatihan pengenalan ilmu computer diberikan dengan bentuk simulasi coding dengan Bahasa Blockly. Platform yang dipilih adalah Code.org ${ }^{\circledR}$. Code.org ${ }^{\circledR}$ adalah lembaga nonprofit yang didedikasikan untuk memperluas akses ke ilmu komputer di sekolah dan meningkatkan partisipasi perempuan dan minoritas yang kurang terwakili (Code.org, 2017). Materi yang diberikan adalah materi dari kurikulum Code.org yang dikhususkan untuk siswa SD - SMA. Kurikulum ini dipecah kepada tiga tingkatan, salah satunya adalah Computer Sciences Principles (Code.org, 2017).

Coding dengan simulasi Blockly dilakukan dengan menggunakan perangkat/ gadget yang dimiliki oleh peserta. Perangkat yang digunakan tidak terbatas pada satu jenis perangkat, namun dapat menggunakan laptop, smartphone ataupun tablet, sehingga pelaksanaan simulasi coding dapat dilakukan oleh siapa saja, selama perangkatnya terhubung dengan internet dan dapat mengakses web browser.

Kegiatan pelatihan dilaksanakan pada Hari Sabtu tanggal 4 Agustus 2018, bertempat di Auditorium Arifin Panigoro, dengan target peserta adalah siswa SMA Islam Al Azhar 1, 2 dan 3 Jakarta. Melalui sosialisasi dan pelatihan tersebut, diharapkan siswa-siswa di sekolah mendapatkan pengetahuan dan memberikan pelajaran kepada siswa bagaimana menyelesaikan permasalahan secara sistematis dan dapat meningkatkan kreativitas mereka. Kegiatan ini tidak hanya diikuti oleh siswa, tapi juga diikuti oleh guru dan bagian kurikulum sehingga pesan pentingnya Ilmu Komputer sampai kepada pihak sekolah. Dengan begitu diharapkan dapat menjadi pertimbangan bagi pihak sekolah untuk memberika pelajaran Ilmu Komputer kepada siswa.

\section{HASIL DAN PEMBAHASAN}

Pada awalnya, target peserta hanya 50 siswa yaitu sebanyak dua kelas. Namun pada saat audinesi dengan pihak Dikdasmen YPI Al Azhar menawarkan untuk pelatihan dapat diberikan kepasa siswa-siswa SMAI 1, 2 dan 3, sehingga terdapat perubahan rencana pelaksanaan kegiatan, mulai dari tempat dan waktu. Target peserta menjadi 200 siswa sesuai dengan daya tamping tempat di Auditorium Arifin Panigoro UAI. Pada saat pelaksanaan peserta yang ikut sebanyak 126 siswa. Hal ini dikarenakan sebagian siswa, khususnya siswa kelas XI IPA mengikuti pembinaan siswa kelas XI yang sudah diagendakan di sekolah.

Kegiatan pelatihan Programming dipecah kedalam dua sesi kegiatan. Kegiatan yang pertama adalah penyampaian materi mengenai Coding dan pentingnya belajar Coding yang disampaikan oleh bapak Dr. Ade Jamal.

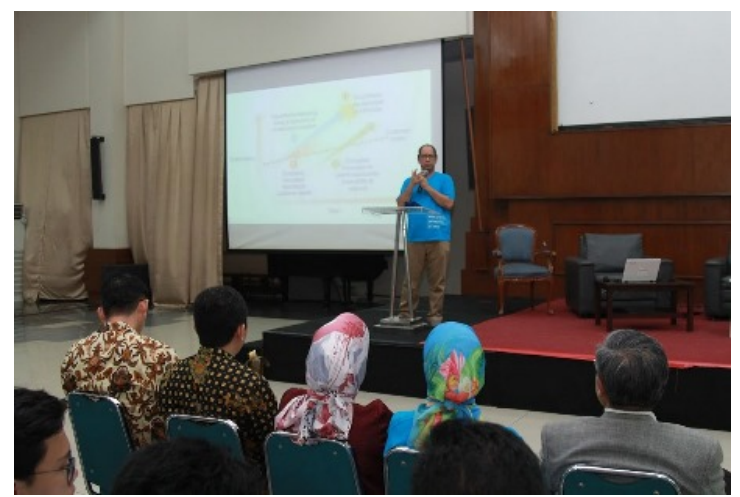

Gambar 1. Penyampaian Materi Oleh Dr. Ade Jamal

Kemudian dilanjutkan dengan Workshop Hour of Code, dimana setiap siswa mencoba belajar coding menggunakan smartphone mereka masing-masing. Dalam kegiatan ini, siswa menyelesaikan permasalahanpermasalahan yang diberikan dalam bentuk games, dengan menyusun puzzle yang berisikan blok program. Blok program yang telah disusun, kemudian dijalankan untuk melihat algoritma dan perintah yang diberikan dapat menjawab permasalahan atau harus direvisi dan diperbaiki. 


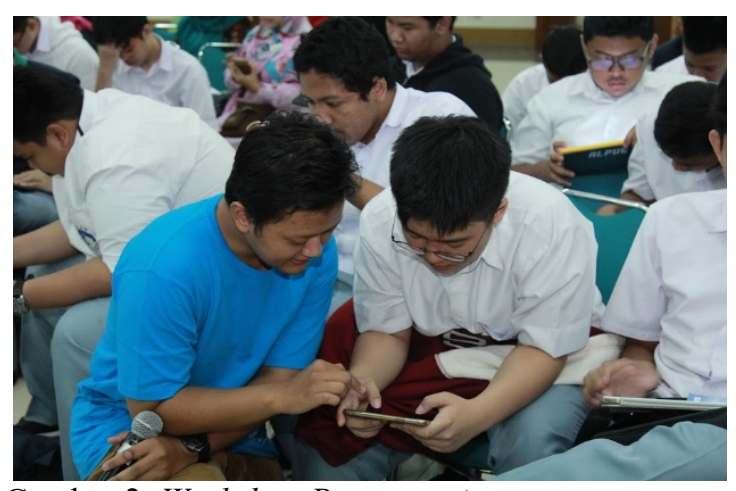

Gambar 2. Workshop Programming

Setelah menyelesaikan satu siklus simulasi, siswa akan diberikan sertifikat online langsung dari Code.org sesuai dengan games simulasi yang dikerjakan. Kegiatan selanjutnya adalah penyerahan sertifikat kepada peserta yang telah menyelesaikan satu set programming. Penyerahan sertifikat diwakilkan kepada Rektor UAI, Perwakilan Dikdasmen YPI Al Azhar dan perwakilan mahasiswa.

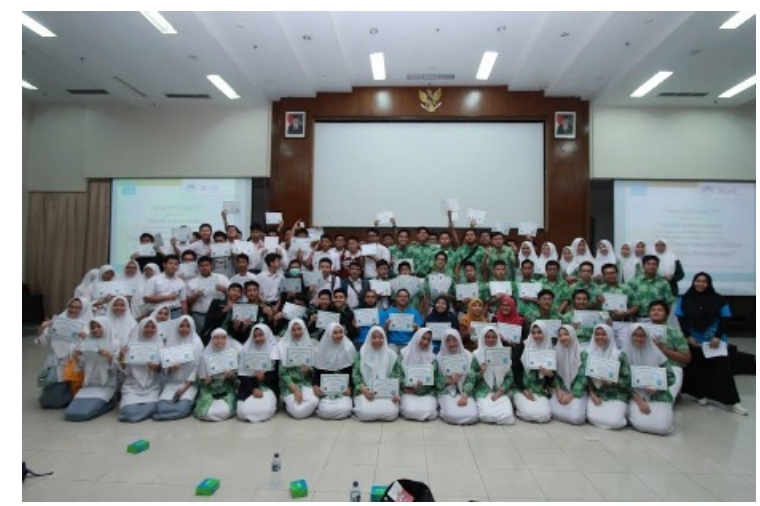

Gambar 3. Foto Bersama Panitia dan Peserta

Secara keseluruhan pelaksanaan kegiatan berjalan dengan lancar. Kegiatan dimulai tepat waktu dan sesuai dengan jadwal yang sudah ditetapkan. Kekurangan dari kegiatan kali ini adalah kurangnya koordinasi dengan panitia sebagai asisten, dan belum ada briefing dengan mahasiswa mengenai materi yang akan disampaikan sehingga beberapa kali mahasiswa kurang dapat menjelaskan atau menjawab pertanyaan dari peserta. Kekurangan ini akan menjadi catatan untuk perbaikan pelaksanaan kegiatan di masa mendatang.

Sebagai bahan evaluasi dalam kegiatan ini, para peserta diminta untuk mengisi kuesioner yang telah disiapkan secara online. Dari 126 peserta, ada 61 peserta atau sekitar 50\% yang memberikan evaluasi melalui kuesioner online. Dari 61 peserta yang mengisi kuesioner 27,4\% berasal dari SMA Al Azhar 1, 24, 6\% dari SMA
Al Azhar 2 dan sisanya 18\% berasal dari SMA Al Azhar 3. Grafik asal sekolah peserta dapa dilihat pada Gambar 4 berikut.

\section{Asal Sekolah \\ 61 responses}

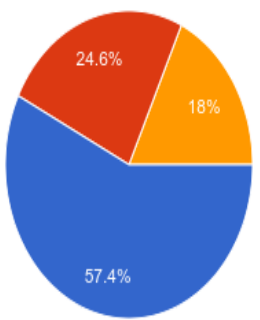

SMAl 1 Al Azhar

SMAI 2 Al Azhar

SMAl 3 Al Azhar

Gambar 4. Persentase Asal Sekolah Peserta

Materi yang disampaikan dalam seminar merupakan materi yang berakaitan tentang pentingnya belajar ilmu komputer, coding, penerapan dan manfaatnya bagi siswa, sekolah dan masyarakat pada umumnya. Para peserta sebagian besar merasa materi yang disampaikan sangat baik dan menarik. Hal ini dapat dilihat dari grafik yang ada di Gambar 5. Pada Gambar 5 terlihat $21,3 \%$ peserta merasa materi yang diberikan sangat menarik, $29,5 \%$ menarik, $27,9 \%$ biasa saja dan sisanya sebanyak $14,6 \%$ dan $6,6 \%$ merasa materi kurang dan tidak menarik.

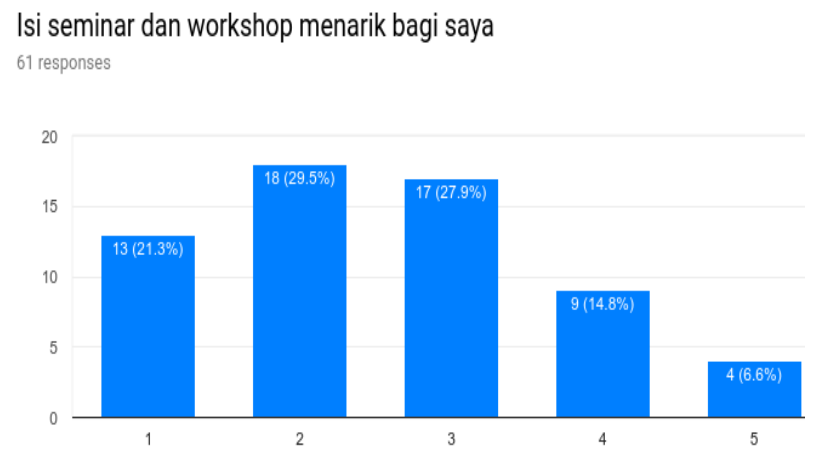

Gambar 5. Evaluasi Isi Seminar Menurut Peserta

Kegiatan workshop atau pelatihan pemrograman (coding) juga merupakan kegiatan yang sangat diminati peserta. Hal ini dikarenakan siswa dapat memberikan perintah dalam bentuk kode program melalui puzzle kepada karakter-karakter yang ada dalam games simulasi. Hal ini terlihat dari hasil kuesioner, dimana sebagian besar siswa, yaitu 29,5\% dan $23 \%$ merasa kegiatan workshop sangat bermanfaat. Hanya $9,8 \%$ dan $6,2 \%$ peserta yang merasa workshop kurang bermanfaat. 


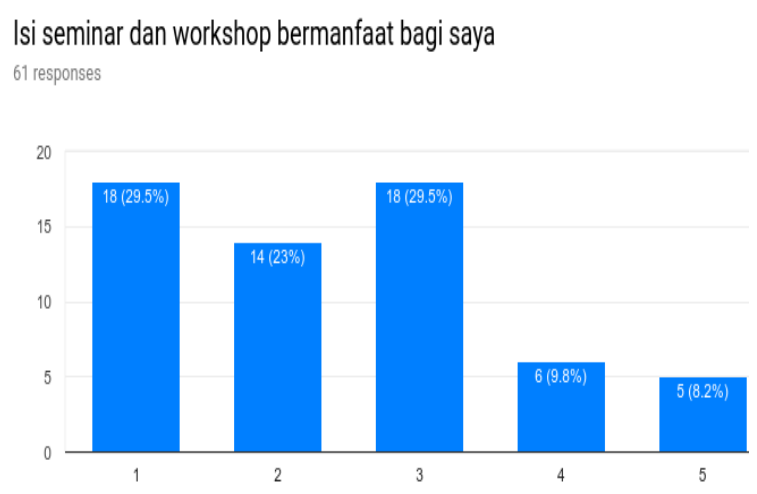

Gambar 6. Manfaat Materi Kegiatan Menurut Peserta

Dengan menggunakan pengolahan hasil kuesioner menggunakan skala likert, didapatkan nilai sebesar $73 \%$ yang artinya, sebagian besar peserta menyatakan bahwa materi yang diberikan bermanfaat bagi peserta. Para peserta juga merasa materi yang diberikan sudah cukup, tidak terlalu banyak dan lama atau terlalu sedikit. Hal ini terlihat dari grafik pada Gambar 7. $88,5 \%$ peserta menyatakan bahwa materi yang diberikan sudah cukup dan sesuai dengan durasi waktu seminar yang diberikan.

Materi/topik yang diberikan pada seminar \&amp; workshop ini 61 responses

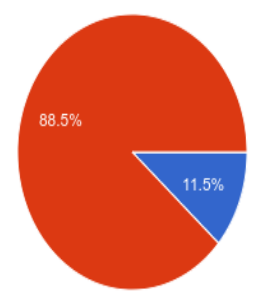

Terlalu Sedikit

- Cukup/Pas

- Terlalu Banyak

Gambar 7. Evaluasi Materi Seminar Menurut Peserta

\section{SIMPULAN DAN SARAN}

\section{Simpulan}

Kegiatan pengabdian masyarakat yang direncanakan yaitu Pengenalan dan Pelatihan Pemrograman Dasar Blockly dengan (Hour of Code $^{T M}$ ) kepada Siswa SMA Al Azhar 1 dan 3 telah selesai dilaksanakan. Target peserta mencapai 64\%, yaitu sebanyak 126 siswa SMAI Al Azhar 1, 2 dan 3. Kegiatan pelatihan berjalan dengan lancar dan dihadiri oleh Siswa, Guru, Dikdasmen YPI Al Azhar.
Berdasarkan hasil kuesioner yang diberikan kepada siswa, dapat disimpulkan beberapa hal yaitu (1) materi yang disampaikan sangat baik dan menarik, yaitu sebesar $21,3 \%$ peserta merasa materi yang diberikan sangat menarik, 29,5\% menarik. (2) Kegiatan pelatihan/workshop bermanfaat dengan nilai likert sebear $73 \%$, dengan $29,5 \%$ peserta menyatakan sangat bermanfaat dan $23 \%$ peserta menyatakan kegiatan workshop bermanfat. (3) Materi yang diberikan sudah sesuai dengan isi dan durasi waktu pelaksanaan, yang dinyatakan oleh $88,5 \%$ peserta.

\section{Saran}

Beberapa saran yang dapat diberikan untuk kegiatan berikutnya adalah lebih banyak mengundang guru-guru TIK, sehingga pesan dan sosialisasi pentingnya Ilmu Komputer juga dapat diterima guru-guru. Disamping itu, perlunya tambahan dana untuk pelaksanaan kegiatan, sehingga peserta merasa nyaman, mulai dari seminar kit dan konsumsi.

\section{UCAPAN TERIMA KASIH}

Ucapan terima kasih kami sampaikan kepada LP2M UAI yang telah memberikan pendanaan untuk kegiatan ini dalam bentuk Grant Abdimas dan juga kepada Dikdasmen YPI Al Azhar atas kerjasama dalam pelaksanaan kegiatan ini.

\section{DAFTAR PUSTAKA}

Code.org. (2017). Computer Science Principles. Diakses dari https://curriculum.code.org/ csp-1718 pada 21 Desember 2017

Code.org. (2017). More information, history, and philosophy. United States. Diakses dari https://code.org/about pada 21 Desember 2017

Csizmadia, A. (2017). Computational Thinking: A Guide for Teachers. Diakses dari http://community.computingatschool.org.uk/ files/8550/original.pdf pada 21 Desember 2017

We Are Social, LTD. (2017). Digital Social in 2017: Global Overview. Diakses dari https://wearesocial.com/specialreports/digital-in-2017-global-overview pada 13 November 2017

World Economic Forum. (2018). Creative Disruption: The Impact of Emerging Technologies on The Creative Economy. 
Pengenalan dan Pelatihan Pemrograman Dasar Blockly kepada Siswa SMA Al Azhar 1,2, dan 3

Diakses dari http://www3.weforum.org/ docs/39655 CREATIVE-DISTRUPTION.pdf pada 13 November 2018 